\title{
"Baby, I am the garbage": James Schuyler's Taste for Waste
}

\author{
Christopher Schmidt
}

Andrew Ross has persuasively argued that camp sensibility occurs "when the products [...] of a much earlier mode of production, which has lost its power to produce and dominate cultural meanings, become available, in the present, for redefinition according to contemporary codes of taste" (312). It is not yet customary to read poetry through the lens of camp. Yet any engaged follower of contemporary verse will recognize in Ross's words a partial description of the genre's occulted status in twenty-first-century literary culture. If camp is a "rediscovery of history's waste" (320), as Ross notes, in this essay I ask to what degree does poetry perform a similar waste management? My test case for this inquiry is New York School poet James Schuyler, whose camp poetics recuperates both bodily and consumer waste.

Schuyler is not the most obviously camp figure among New York School poets. That distinction rests with Frank O'Hara, whose whimsical embrace of pop culture made him an early standard-bearer, and scapegoat, for the camp cause. Schuyler's version of camp is staged not through identification with glamorously self-destructive female stars (by contrast, witness O'Hara's famous line, "Oh Lana Turner we love you get up" [449]), but rather through an unabashed embrace of the abject material of trash and waste. Consider the following pas-

Christopher Schmidt is the author of a book of poems, The Next in Line, winner of the 2007 Slope Editions Book Prize and published in 2008. He is currently working on a book-length study on the poetics of waste mangagement, from which "Baby, I am the garbage: James Schuyler's Taste for Waste" is excerpted. Recent poems, essays, and reviews can also be found in SubStance, Intervalles, LaPetiteZine.org, Tin House, and other publications. He has taught at Bard College, Hunter College, and Brooklyn College. 
sage from Schuyler's diary, which exemplifies the poet's investment in the throwaway as a vehicle of poetic transport and succor:

Just back from Sheridan Square cigar store, where a spacedout young man was laying it on the line for unwary customers-the man just ahead of me got, "Ten billion years older than the oldest living maggot on earth." My sentence was a little lighter: "Take the garbage with you." Walking up Seventh Avenue and passing Tony Holland, who was looking very well, staircase wit made me wish I'd said, "Baby, I am the garbage_-" but for that kind of repartee, a bodyguard is no bad idea. (Diary 113-14)

"Baby, I am the garbage." With just five words, Schuyler offers a definition of camp that resembles Ross's formula but links camp more clearly to queer subjectivity. Schuyler's camp recuperates the deprecated (waste and trash) into a source of queer identity and strength, with special attention to how that identification is routed through the products and waste of late capitalism. Aptly, Schuyler's anecdote occurs in Sheridan Square, the very spot where just three years earlier the Stonewall riots flared-riots in which queers, who had long camped out in wastelands like the seedy, Mafia-run Stonewell Inn, fought back for public recognition and rights within the charmed circle.

The poetry of the New York School emerges from an historical moment when camp was an urgent subcultural expression, making performative not just the marginal status of mid-century queers but also the contamination of the supposedly elite genre of poetry by the "low" art of pop culture. New York School productions went further than any previous-even the work of W.H. Auden, an important New York School forebear-in recognizing the camp potential in the poetic genre itself (not least in Ashbery's jarring and sometimes parodic use of classical verse form). ${ }^{1}$ In the service of their camp poetics, New York School poets often employed waste as a trope, in part to disrupt the "purity" and selfseriousness of the regnant academic style. ${ }^{2}$ Waste, however, has special currency in Schuyler's work. Pop cultural ephemera, garbage, and even excrement are common subjects in Schuyler's poems. Yet Schuyler's poetic waste management is evident not only in his subject matter but in his method as well. In a letter to a reader inquiring about his motivation for writing a poem, Schuyler notes that "what stimulated me to write was the apathy following on the disappointment of a wasted day. However, what seemed like waste may have been a warming up. Who knows? Not me" (Just the Thing 240). Poetry as a recuperation of wasted time-temps perdu - is on one level a hoary cliché: poet as wool-gatherer. But Schuyler redeems this commonplace by making it ramify on every level of his poetics and by translating it into the physical realm.

While the slippage between the various categories of waste-ordure, trash, and indolence-may seem an instance of critical legerdemain, it is precisely Schuyler's traffic between these different registers that lends his work its power. Indeed, the camp that interests me here-and it is a variety of camp at which Schuyler excelled - is not just a recuperation but a confusion of waste. Schuyler's camp is located at the imaginary switch-point between bodily waste and cultural 
waste, between the "damaged" body (the queer body, the fat body) and the larger social body fed the nutritionless disposables of commodity culture; the planned obsolescence of these commodities produces waste, in the form of garbage most obviously, but also in the resources wasted by replacing yesterday's unfashionable purchases with today's newer models.

\section{Trash and Treasures}

In twentieth-century verse, poetry and queer sexuality are frequently, often simultaneously, equated with waste. The mythological crisis defining Eliot's The Waste Land, for example, is a sterility caused by injury to the Fisher King-a sterility that may also implicate the sexual nonreproductiveness of the homosexual. An example more immediately present to Schuyler, however, would have been Lowell's "Skunk Hour," the final poem in his 1959 Life Studies, perhaps the most anthologized poem by America's then most celebrated poet. Lowell's poetic gravity is at the opposite end of the tonal spectrum from New York School camp; in fact, "Skunk Hour" was subject to an attack by O'Hara, who remarked: "I don't think that anyone has to get themselves to go watch lovers in a parking lot necking in order to write a poem [...] They should feel guilty. Why are they snooping? [...] And then if you liken them to skunks putting their noses into garbage pails, you've just done something perfectly revolting" (qtd. in Lehman 347). As Terrell Scott Herring notes, it was likely the notion of surveillance, to which homosexuals in the McCarthyite fifties would have been especially sensitive, that grounds O'Hara's attack (416). Yet the virulence of O'Hara's attack on "Skunk Hour" makes the poem all the more relevant to considerations of New York School productions. Despite its distance from the New York School ethos and aesthetic, "Skunk Hour" describes the camp sensibility with phobic precision-perhaps another reason for O'Hara's hostility. In the fourth stanza of "Skunk Hour," Lowell problematically isolates the camp work of the "fairy" as an index of Nautilus Island's decay:

And now our fairy

decorator brightens his shop for fall;

his fishnet's filled with orange cork, orange, his cobbler's bench and awl;

there is no money in his work,

he'd rather marry. (191)

As in Eliot, sterility occasions poetic crisis. Producers have escaped the island, leaving the landmass to unproductive consumers: a colonizing dowager and a parasitical homosexual, who transforms traditionally masculine means of livelihood-fisherman's nets and a cobbler's phallic awl-into feminine, fruit-colored consumables. The fairy renders the butch tools of production decorative, camping them. Lowell's "Skunk Hour" ends with the eponymous animal rooting morsels - "sour cream"- out of spilled garbage (192). The skunk seems meant to represent the troubled, mentally ill Lowell, with trash-picking an index of the poet's debasement. But Lowell's poem also suggests that the retrospective work of the autobiographical poet, shoring fragments against one's own ruin, is at base a scavenging mode. Lowell is skunk-like not merely because he is mad; as 
a poet, Lowell is pressed to pick over the ignoble discards of memory. As Baudelaire recognized, the modern poet is cousin to the rag-picker.

In a later poem, Schuyler would suggest that his own poetry, even more than Baudelaire's or Lowell's, finds its origins in waste management. A novelist before he was a poet, Schuyler worked for Auden on Ischia in 1949, typing the poet's manuscripts. While Schuyler would distance himself from Auden's perfectly wrought and formally controlled work-commenting, "Well, if this is poetry, I'm certainly never going to write any myself' (qtd. in Lehman 259)-his recollection of his time working for Auden bears some resemblance to Lowell's "Skunk Hour" in that Schuyler, like Lowell's skunk, finds the value in trashed discards. What may well be a primal scene in Schuyler's poetic development is recounted in his later elegy for the poet "Wystan Auden":

when [Auden] learned that in Florence

I and my friend Bill Aalto had

fished his drafts of poems

out of the wastepaper basket, he took to burning them, saying,

"I feel like an ambassador burning

secret papers." (Collected Poems 243)

Practically speaking, Schuyler was likely scavenging Auden's drafts for their resale value. But if Schuyler's transcription for Auden was a kind of poetic antiapprenticeship, it is telling that Schuyler finds the trashed manuscripts more compelling than Auden's completed poems. Rooting in the trash would become for Schuyler, master of the throwaway, a template for future poetic sorties.

Where Lowell theatricalizes his debasement through trash, and Auden destroys his discards so as to prevent them from competing with his finished work, Schuyler recuperates the trash into a vehicle of poetic inspiration and erotic transport. In a suite of poems from his second book, The Crystal Lithium, Schuyler elaborates a kind of ars poetica which explores the imaginative and erotic possibilities afforded by poetic waste management. ${ }^{3}$ The three poems, "After Joe was at the island," "Used Handkerchiefs 5ф," and "The Trash Book," are either implicitly or explicitly addressed to Schuyler's friend Joe Brainard, an important artist and collagist. In "After Joe was at the island," Schuyler lingers in the aura of the "east sleeping porch he used as a studio" (98), where Brainard's traces are evident in leftover art-making materials. The primary use value of these objects had already been exhausted when they were taken up for art making; they are now doubly exhausted-leftovers of leftovers-as they make their way into Schuyler's poem: "torn-out book matches with burnt heads pointing all one way, laid in a likeness of a woodpile (always making something); and a pastryboard drawing board with edge of the paper color traces" (98). As much as Brainard's collage aesthetic mines the refuse of pop culture, Schuyler's poetry goes a step further by finding value in detritus even the collage artist couldn't make useful.

The suite's second poem, "'Used Handkerchiefs 5 $\varnothing$," begins as a catalog of what seems to be a "trash-and-treasure" sale, in which Schuyler finds used handkerchiefs, "a dresser scarf," "a pillowcase full of carpet scraps," "bent giant post- 
cards," and finally a figure (likely Brainard) who is apostrophized in a tone flickering between nostalgia and lambent eroticism:

[T] hen there is your face, floating up the stairs, big-eyed into the trash-and-treasures loft from which, finally, dressed for tennis as you came, you go down again with a find in hand: a slab of undyed linen its silverness yellowing like a teaspoon from egg yolk. (99)

Brainard emerges with a decidedly feminine find, whose misuse Schuyler diagnoses precisely: "[linen] ironed with too cool an iron so the washing crush marks make a pattern over the weave and, above the thick welt of the hem, a crossstitched border of spruce and juniper unstylized (unless style is simply to choose)" (99). In some ways the very point of the collage aesthetic employed here, and modeled by Brainard, is "simply to choose." Because collage privileges choice and juxtaposition over aesthetic transformation, it is a desublimation-or at least an alternative to sublimation-consonant with Schuyler's larger aesthetic approach.

The Brainard suite of poems ends with "The Trash Book," a poem that bears an explicit dedication to Brainard and describes a trash book that Schuyler prepared as a present to the artist. What is a trash book? In a 1970 letter to Brainard, Schuyler explains:

As soon as I got here I started to make you a trash book out of an address book I had never used. I thought it would take about an hour, but who would guess that an address book, such a little itty bitty address book, could have so many pages? Or that one's trash runs out so soon? A trash book, in case you're wondering, is something like a scrap book, only, well, you put trash in it. Which is not the same as garbage. That you put in boxes, like a candy box, and call it a Garbage Box. Garbage Boxes are not quite so nice as Trash Books. (Just the Thing 298)

Among the many examples of "trash art" then ascendant, Schuyler may have had in mind the sculptures and "combines" of Robert Rauschenberg, the "Large Bourgeois Refuse" containers of Arman, or even Joseph Cornell's assemblages, boxed tableaux created from publicity stills and other ephemera which are steeped in nostalgia and desire. If these types of artwork qualify as "Garbage Boxes," it is somewhat unclear how Schuyler's "trash book" would have differed. Also unclear is the exact nature of the trash book's relationship to Schuyler's poem "The Trash Book," one of his most subtly accomplished and tender works:

Then I do not know what

to paste next in the

Trash Book: grass, pretending

to be a smear maybe or

that stump there that knows

now it will never grow

up to be some pencils or

a yacht even. A piece of

voice saying (it sounds like)

"I thought her did." Or

the hum that hangs in only 
my left ear. Or, "Beer" not

beer, all wet, the quiver

of the word one night in

1942 looking at a cardboard

girl sitting on a moon in

West Virginia. She smiled

and sipped her Miller's. (Collected Poems 99-100)

Note how the poem, opening in medias res, echoes Schuyler's vision of Brainard in "Used Handkerchiefs 5 $\phi$ ": "then there is your face" ... "Then I do not know what / to paste next in the / Trash Book." Schuyler's poem-indeed, the entire Brainard suite of poems-exemplifies and eroticizes the beauties of the contingent, the interrupted, the mediated.

Although "The Trash Book" begins as a paean to matter in its most material state, it does things only a poem could do. This literary trash book includes objects-a stump - that could not easily fit inside an actual address book. It measures quiddity not in matter, or even in matter's mark, but in the pantomime of matter's trace: "grass, pretending / to be a smear maybe" (emphasis mine). Moreover, it extends its consideration beyond objects' fallen materiality to imagine other potential incarnations ("now it will never grow / up to be some pencils or / a yacht even," a knowing pathetic fallacy, of the vegetal variety). The poem also dilates on language itself, highlighting the uniquely linguistic delights of errant syntax ("I thought her did"), tone ("the hum that hangs in only / my left ear") and reference, the ability of language to evoke sensual pleasure without risking spill or hangover: 'Or, 'Beer' not / beer, all wet, the quiver / of the word one night in / 1942" (99). Language, in its ability to gesture towards absent objects, has at least one advantage over gross matter-it's less sticky.

What seems at first an homage to the trash book ends as a testament to its failure, relative to the poem, to recuperate life in all its complexities (even the complexities of exhausted materiality). "The Trash Book" is Schuyler's version of O'Hara's "Why I Am Not a Painter," a testament to the power of poetry, disguised as a meditation on another medium. Though this suite of poems admits Brainard's influence, Schuyler finally adapts the collage aesthetic to his own ends, making it expressive and expansive. Schuyler's trash-oriented verse inhabits the same force field as the Garbage Box and the Trash Book, with the difference that Schuyler, in his poems, successfully reanimates waste.

How should we read that last, inexplicably moving image of "The Trash Book," which Schuyler forces us to disentangle from dizzyingly placed clauses: "one night in / 1942 looking at a cardboard / girl sitting on a moon in / West Virginia. She smiled / and sipped her Miller's"? Schuyler's imprecise ordering of clauses in the passage has a dizzying, dislocating effect ("sitting on a moon in / West Virginia") that echoes the surreal effects of advertising. The trope is almost certainly autobiographical: in 1942, Schuyler attended Bethany College, in West Virginia, where he likely saw what I take to be a Miller's advertisement of a girl sitting on a moon. Maybe Schuyler even got trashed-inebriated-on Miller's beer, perhaps saw himself as that Miller's girl. Even at that time, queer Schuyler 
would likely have held an oblique, tangential, identificatory, rather than purely desiring, relationship to this Miller girl. In other words, the Miller girl's solicitation of Schuyler's desire, her hailing of him in the interests of promoting commodity fetishism, was recognized but met aslant. This detached, ironic response to the needy address of the commodity-picture the Miller girl leaning in to lock lips, to be met instead with a precise air kiss-is where camp begins.

Mining the poignancy of failed desire, camp thrives on the misdirected address of the commodity, haunted by its own imminent obsolescence. I imagine that this Miller girl resembles the Vargas girl, all airbrushed flesh and wholesome come-on, because camp seems to respond especially well to sites of desire when the putative heterosexual object is varnished with distancing, queer-making artifice; when heterosexual desire and homosexual irony are written, as if in palimpsest, on the same cultural locus. These items, for the queer lover, are fetishes in not just the Marxian but also the Freudian sense of the word, in that they seem to operate as symbolic containers for the resolution of desires and identifications too intense to be resolved directly and are instead mediated by the commodity fetish. Trash does not just emblematize queerness, it mediates it and, I would argue, offers a circuit through which queer desire can be circulated, buffered, and contained.

Brainard is not the only friend to whom Schuyler relates via a triangulation with the objects and icons of commodity culture. ${ }^{4}$ In "The Morning of the Poem," Schuyler writes, "When I first knew John Ashbery he slipped me / One of his trick questions (we were looking at a window / full of knitted ribbon dresses): 'I don't think / James Joyce is any good: do you?"' (286). Here taste-making occurs through a critique of modernist literature. (A similar exchange seems to have occurred when O'Hara and Ashbery first met, with camp novelist Ronald Firbank trumping Henry Fielding [Gooch 138].) Yet note how Schuyler locates this exchange in front of a shop window, in which the two poets regard a tableau of dresses. Beyond indicating the gay man's feminization, I would argue this arrangement is the very template of a certain kind of gay male friendship, in which gay men triangulate with a female or feminized commodity, whether it be a star, a dress, or a Miller beer spokesmodel. This identification solidifies friendship but also screens against desire, keeping the gaze directed towards an object that refracts, rather than captures, cupid's gaze. Following on the Girardian schema of homosocial desire explored by Eve Sedgwick in Between Men and Wayne Koestenbaum in Double Talk, I am suggesting that camp is a way of both binding gay men together and of rerouting their eroticism; the feminized camp object-trash-absorbs the gay gaze, mediating it, much as the woman, in Sedgwick's schema, and the collaborative text, in Koestenbaum's, offer a circuit through which various male-male energies are transferred. ${ }^{5}$

To be clear, I am not arguing that camp is anerotic, a position Leo Bersani, for example, advances in his essay "Is the Rectum a Grave?" Bersani argues that camp, an implicitly feminine mode, wilts libido because gay men desire only masculine personality traits-a position that overlooks the strong erotic and fetishistic aspects of camp, however sublimated and redirected, as well as the di- 
versity of erotic predilections in queer life. At times, Schuyler does characterize camp negatively, as in the following remembrance from his late poem, $\mathrm{AFew}$ Days, in which the camp declaration- "I order you back to your ship"-seems offered precisely to curtail over-zealous sexual excitement:

Billy was the Navy officer who, when he was

getting fucked by an apelike sailor, lifted his head out of the pillow and

said, "I order you back to your ship." His camp name was Miss Williemae.

He was a virologist who detected two new viruses, which he named for Chester

Kallman and me: Fiordiligi and Dorabella. If anybody called me by my camp name

nowadays I'd sock them-I like to think. I remember how I felt when Chester

dedicated his book to me and wrote the poem in "camp": "Wearing

a garden hat her mother

wore..." Bitch. (368)

Although Schuyler here seems to disdain camp, the passage is by that same token one of the most tonally campy and flirtatious in his poetry. Schuyler's attitude seems typical of the attractions and ambivalences, erotic and otherwise, camp solicited among gay men in the post-war period. Schuyler wrote the passage above in the early eighties, looking back on a scene that would have occurred almost three decades earlier, when butch and femme sexual roles- "trade" and "fairies"-were more entrenched and punishing. Racism, class alliance, and ageism are also factors in any mid-century camp constellation, as Schuyler suggests in the following remembered anecdote between the poet and his first lover, Bill Aalto:

Bill never let me forget that on the jukebox I kept playing Lena Horne's "Mad About the Boy."

Why the nagging teasing? It's

a great performance but he thought it was East Fifties queen taste. (249)

While race and class divisions in the gay community ("Lena Horne," "East Fifties queen taste") contribute to the lovers' disagreement, the passage also makes evident many gay men's phobic resistance to camp as a performance of crossgender identifications anathema to those who aim for a more masculine selfpresentation (Schuyler nevertheless undermines the imputed "butchness" of Aalto by ascribing to him maternal and infantile qualities: nagging and teasing). Disdain for camp is by no means exclusive to the gay community but characterizes as well the heterosexual response to a "taste" that is too openly, too performatively gay. While misogyny often underlies such homophobia, I want to suggest, in the next section of this essay, that such distaste is also born out of a recognition that camp entails acquiring a "taste for waste"-a waste that is itself feminized, 
whether in its raw organic form, or in the feminized "domestic" objects often valued in camp resuscitation. ${ }^{6}$

\section{Camp and the Taste of Waste}

When critics call something "camp," they usually leverage the term as a slight, particularly, it seems, if the critic's specialty is poetry. W.S. Di Piero, reviewing a posthumous collection of Schuyler's letters, writes, "He camps it up more in the letters than in the poems. He becomes Jimmy 'the fag,' Jimmy the (sort of) dandified flâneur ... and writes about others' affairs with the terrier snappiness of a society columnist. The trivia seems to clutter the space where an inner life should be. [...] The nonstop name-dropping, though, can induce a kind of mild food disgust" (308). Likewise, in an otherwise appreciative review of Schuyler's Selected Poems in the September 28, 1988 issue of the New York Review of Books, Helen Vendler pauses to admit the poet's "defects," in terms that also implicate the gustatory, albeit in less obvious terms than Di Piero does. Generally, Vendler is more keenly alive to poetic failings among practitioners whose lines fall nearer the rawer end of the poetic spectrum than the cooked. ${ }^{7}$ Accordingly, when Vendler deploys the camp epithet as negative criticism in her review of Schuyler's work, the closest she comes to defining the term is by aligning it with an unpleasant taste. She cites the following passage from "A Few Days," a masterpiece she doesn't name, as "neither so campy as some in Schuyler's writing nor so bittersweet as others, but" one that provides "a fairly random sample of the problems raised by Schuyler's later work" (357). Yet what seems most salient to me about this passage is not so much Schuyler's campiness as his privileging of taste and other forms of oral pleasure:

good at interpreting

I'm no

dreams. Hands fumble with clothes, and just at the delirious moment I wake up:

Is a wet dream too much to ask for? Time for a cigarette. Why are

pleasures bad for you?

But how good the tobacco smoke tastes. Uhm. Blow smoke rings

if you can. Or

blow me: I could do with a little carnal relief. The yard slopes down to a swampy bit,

then fields rise up where cows are pastured. They do nothing all day but eat:

filling their faces so they'll have a cud to chew on. I'm not uncowlike myself: life as a

continuous snack. Another ham-salad sandwich and then goodbye. (357)

Taste, in the aesthetic sense, involves exclusion: "Elegance is refusal," barked Diana Vreeland, famously. Yet in the gustatory sense, taste is coextensive with consumption, if not overconsumption (though, by that same token, it can also be employed to suggest a measured sampling-"just a taste"). Both these senses of 
taste-connoisseurial and consumptive-are employed in the many definitions of camp, though often by different theorists. Sontag: "Camp asserts that good taste is not simply good taste; that there exists, indeed, a good taste of bad taste" (65). Caryl Flinn: "Camp entails an excess of consumption, a wasted production that is literalized by/on female bodies" (443). Schuyler's genius is to combine both senses of camp taste in one poetics. In his New York School study, The Last Avant-Garde, David Lehman described Schuyler as the group's "editor par excellence"; the poet edited two editions of Locus Solus, the New York School's unofficial and sporadic publishing organ, and provided valuable commentary on the other poets' works-notably, Kenneth Koch's Wishes, Lies, and Dreams, a primer for the teaching of poetry (74-6). In other words, Schuyler was an arbiter of New York School taste. But in his own work, Schuyler more openly embraces "bad taste," perhaps especially when it admits the bad taste of (fattening) food: "another ham-salad sandwich and then goodbye." Schuyler has a way of literalizing camp taste, and sliding between the connoisseurial and the gluttonous with perverse pleasure.

Perhaps what Vendler found distastefully campy in the passage above was Schuyler's slide from oral habit ("tobacco") to oral sex act ("blow me") to processed oral morsel ("ham-salad sandwich")-precisely because here the poet seems to sample the vulgar, in all its low permutations (swamp, livestock, cheap snack, cheap come-on) and savor the "slop[ing]" debasement of such tastings. But for me, the most resonant figure in the above passage, one that I take as a kind of emblem of the version of camp I'm exploring in this essay, is Schuyler's notion of himself as a ruminant, one of the cows who "do nothing all day / but eat: filling their faces so they'll have a cud to chew on. I'm not uncowlike / myself: life as a / continuous snack." What's remarkable is how this trope manages to combine two aspects of camp sensibility: camp as excessive consumption and camp as recycling or, in this case, retasting. The cow rechews its own food; like the camp artist, he consumes what has already been once consumed. Schuyler's performative irony and self-deprecation about his excessive digestion resonate with Flinn's notion that camp adheres to the excessive female body (e.g., Mae West, Jayne Mansfield, Divine). Schuyler's self-described "too chubby" queer body arguably reads as feminized in its excessive bulk, a wasted consumption about which Schuyler was all too ruefully aware (Collected Poems 359). Schuyler waxing dietetic is Schuyler at his campiest, as revealed in the following letter from Schuyler to Brainard's partner, poet, and publisher Kenward Elmslie:

I'm joining Joe in making 1970 the biggest and best summer of deprivation yet. I'm giving up food. It's that, or Fatties Anonymous will start building elephant traps for me. One thing that helps, in a sense, is that I brought no booze, not even curdled grape juice. Then too once the stove has gone out for the night there's not such a temptation to start running up bacon and peanut butter samadges-yes dieting's going to be real easy; but I'd better stop talking about it or I will have to go finish off the cold boiled potatoes. (Just the Thing 296)

Signally, Schuyler ends his performance with the invocation of tempting left- 
overs ("cold boiled potatoes"). If Schuyler had an especially acute relationship to the leftovers that often comprise camp practice, it may be because he lived much of his life subsisting on the surplus of his wealthier and more successful friends. (Schuyler wrote the above letter from the Maine home of painter Fairfield Porter, who supported Schuyler and invited him into his family's home until the poet's mental imbalances became unmanageable.)

As Schuyler's bodily form was subject to alternating periods of expansion and slimming, so are the forms of Schuyler's two greatest long poems- the late masterpieces "The Morning of the Poem" and "A Few Days"-distinguished by lines that alternately swell and contract. The following passage from "A Few Days" seems almost to describe the poem's own systolic-diastolic form:

So I waste my

money on cut flowers. I'm spoiled: I'm used to gathering

flowers for the house,

not buying them. Thirty-five dollars for a dozen roses, Sterling Silver:

not today. Always thinking about what things cost: well, I have to, except

when a cab comes in my view: then I flag it down.

I'd be scared to

figure up how much I spend a year on chauffeur-driven comfort. I'd like to spend part of this lovely

day in a darkened movie theater: only there's nothing I want to see. Fellini's

Orchestra Rehearsal was too much like Alice in Orchestralia. Perhaps a good

walk is more what's called for. I could tool down to Dave's Pot Belly

and have a butterscotch sundae: eating on the pounds I walked off. Or

I could go shopping: I need cologne. Taylor's Eau de Portugal for choice. In the

country you can take a walk without spending money. In the city it isn't

easy. (Collected Poems 365)

Schuyler's seemingly offhand narration of a day's pleasures and expenses is embodied in the form containing it. Expansion (a long line) is followed by a contraction (a short line), like the tightening of a belt around a distended waist. If camp flairs when the body, whether the feminine body or the fat body, is excessively figured ("I could tool down to / Dave's Pot Belly"), in Schuyler's two late masterpieces, the entire poem becomes camp, with the line itself a reflection of the poem's excess. Schuyler relates alimentary economy and the cultural economy of consumer spending; consumption of old movies - a popular camp practice-is associated with excessive caloric intake. Though the poet facetiously bemoans his spending and eating habits, Schuyler's overconsumption (a form of wastefulness) is fundamental to his camp poetics.

Schuyler slides between the two registers of taste in his almost simultaneous 
consumption of pop culture and calories, and in the process effectively blurs the boundaries between tasting and wasting. The trope that both opens and closes "The Morning of the Poem" is the image of the poet urinating, and in both cases, waste-making is juxtaposed with the opposite end of the alimentary process: the ingestion of food and drink. In the opening section of "The Morning of the Poem," Schuyler apostrophizes the poem's ostensible addressee, painter Darragh Park, by focusing on their differing habits of morning repast: "you drink / Your Ovaltine and climb to the city roof, 'to / find a view,' and / I being whoever I am get out of bed holding / my cock and go to piss / Then to the kitchen to make coffee and toast" (259). The scene exemplifies Schuyler's candor in describing the bodily rhythms that comprise daily existence, to which a writer untroubled by the rhythms of wage work may have been especially attentive.

This theme takes on greater symbolic heft when viewed in light of its pendant scene, at the poem's end, in which young Schuyler, "bombed on Pernod," soils himself in a Paris "vespasienne"-a traumatic and highly charged memory (302). In retrospect, Schuyler realizes that his shame was ill-founded: "it never occurred to me that if I'd spilled a / drink in a café, I'd have looked the same" (303). At the poem's beginning, taste and waste are associated by mere proximity, but in the poem's ending, the linkage between the consumed and the wasted is one of confusion, reversal, resemblance, and substitution. I can think of no other poet who sets so many of his poems in bathrooms-Schuyler has exquisite taste in porcelain-and the effect is to bring waste-making out of the (water) closet and onto the dinner table. ${ }^{8}$

\section{The End}

To make the claim that camp is the taste of waste depends on a quick reversal of metaphors, in which consumer consumption (say, the purchase of an All About Eve deluxe box set) is likened to alimentary consumption-of a ham-salad sandwich or, perhaps more aptly, the cow's already twice-consumed cud. Such metaphoric displacement may be the very point of camp. Camp is often inflected by obsession and fetishization, in which a relatively neutral object is charged with erotic energy so that the subject may resolve libidinal attachments too intense to be confronted without the benefit of projection. For example, the opera queen may fetishize the diva in order to witness, in an external theater governed by rituals whose precise demands balance the irrational passions of desire, ramifications of the opera queen's own "feminine" voice, theatrics, and identifications. In object-oriented camp, the consumer marketplace serves as a kind of theater in which more embodied problematics of consumption and waste-making are externalized. This metaphoric correspondence between the body and the marketplace is not exclusive to Schuyler's work. Eve Sedgwick and Michael Moon, in their essay "Divinity," examine in the oeuvre of John Waters some of the ways that the fat body problematizes and dramatizes capitalist overconsumption, especially during the post-war period, in which concern about the earth's ecology emerged "much less from the question of how to feed its inhabitants than from that of how to contain or innocuously to recirculate its wastes" (235). 
(It is surely no coincidence that the most famous scene within the oeuvre of this campiest of film directors is the moment in Pink Flamingoes when Divine eats dogshit.) The swollen, "damaged" body becomes a metaphor for the ravages of societal overconsumption. The symbolically charged figure that emerges in this camp traffic between the body and the social body is that of homo sapiens consuming, if not its own waste, then the waste of others.

I have, thus far, been discussing the relationships between camp, consumption, and homosexuality as if these categories were divorced from the sexual practices that mark the difference between queer and "normative" subjects. The supposed abjections of queer desire-and more specifically, the embodied abjections of gay male desire-may underwrite this triangulation of camp, consumption, and homosexuality. If gay men have traditionally displayed a strong interest in camp and the consumer-culture waste that comprises it, perhaps it is because anal sex, the endpoint of many gay men's sexual practices, puts desire in close congress with bodily waste. The camp object- "history's waste"-may be a fetish or objective correlative or Kleinian "external object" through which the anal-erotic subject can recuperate and, in a Kleinian sense, play with the bodily waste that often attends anal eroticism. The specter of excrement at the center of many gay male sexual practices-though anal sex is of course neither an exclusively gay or an exclusively male practice-necessitates a negotiation of material that has been deemed, since toilet training, unclean, shameful, abject. The gay male sexual imaginary thus requires a negotiation of waste, resulting, in some quarters, in a fantasy male body of impossible cleanliness - witness the depilated, statuary-like self-possession of the porn model. At the other end of the spectrum is the eroticization of waste: "scat."

This précis on the mechanics of anal sex deserves a far more sophisticated analysis than I am able to provide in the limited space of this essay. Certainly the positions sketched above are only two of many points on a spectrum of sexual responses crossed by innumerable axes besides those of cleanliness/waste. But I establish those poles, however provisionally, in order to make legible Schuyler's own telling position on the axis. Witness the following tableau from Schuyler's late masterpiece, "The Morning of the Poem," in which eros, nostalgia, and waste phantasmatically commingle:

I wish it was 1938 or '39 again and Bernie was sleeping

With me in the tent at the back of the yard the time we got up

In the starry night and went downhill, down Olean Road, downhill again

And through the pasture where the cows coughed and exhaled warm breath,

Barefoot among the cow flops (Dutchman's razors) and stands of thistles and

Buttercups the cows won't eat (if you're not

a farm boy, coming up against

A cow the size of a battleship is not unnerving) (now what 
was the name of that boy, the cowfucker,

Who lived down Olean Road? To each his own) (282-3)

Schuyler has often been labeled a pastoral poet, or at least the New York School poet most oriented toward the natural world. But Schuyler's pastoral is compelling precisely because he limns its less savory aspects: when cows and, more to the point, cow flops crowd the landscape (that Schuyler describes the animal's waste using a reference coined from commodity culture-the Dutchman's razor ${ }^{9}$ - speaks to the traffic between the body and the social body described elsewhere in Schuyler's camp poetics). The passage above also reveals how Schuyler's sexuality keeps close company with waste. The scene has the fabular quality of a false memory, with the cow flops populating Schuyler's childhood idyll standing in, phantasmatically, for the waste that would attend anal sex later in life-shit that must be, like the battleship, either navigated around or engaged directly. Did the adult gay man invent this scene, a genesis story of sexual identity, so as to lend luster or explanatory force to his adult "fringe" sexuality (exemplified here in the "cowfucker"), whose behavior is an index of "spoiled identity" and of a "wasted life"?

The importance of waste to Schuyler's poetics lies not only in its possible erotic charge, but also in its relationship to language and its origins as (soiled) oral production. In this passage from his letters, Schuyler comes nearest to essaying the coprophagic imaginary - the taste of waste-which his camp poetics all but names:

I have written a poem for your delectation which I will send as soon as A) I learn to type, and B) find my frigging glasses. They are probably, as usual, up my butt, as they usually are. Or up Tom's. Would they were. (I should warn you that during a hospital stay a black nurse, said of me to a visitor. "This old man has one dirty mouth." OOPS! As Miss Master (W.H. Auden) used to say, "The cheek!" (JTT 412)

Schuyler, in his late work, makes a camp virtue of the foul mouth. In his vertiginous associative slide from the derriere of his young assistant Tom Carey to his own "dirty mouth," the reader must wonder, is the mouth "dirty" from a just fantasized rimming? (Schuyler, as I hope I've shown, is wonderfully agile in slipping almost unnoticed between the metaphoric and the literal.) Auden's exclamation, "The cheek!," with its camp outrage at some display of effrontery, is entirely apropos for the phrase condenses the passage's totalizing dislocations of orality and anality. (It is also important to note Schuyler's problematic invocation of the "black nurse" and "Master," though a fuller explication of the relationship between racial abjection and waste is beyond the scope of this writing. ${ }^{10}$ )

If Schuyler's glasses are a stand-in for his poetic vision, it is appropriate that they are found "up my butt [...] Or up Tom's," for Schuyler's vision is a signally excremental vision, as Norman O. Brown famously characterized the writing of Jonathan Swift. Schuyler, like Swift, understands how waste can disrupt the decorum of the social sphere; as he learned in the Paris vespasienne, waste is a source of shame. But as a poet who would find his voice by embracing queer desires and ungainly excesses, Schuyler exemplifies the recuperative and playful 
ethos of camp waste management, showing us that waste matters. Yeats, in his late Crazy Jane poems, wrote with some despair that "Love has pitched itself in the house of excrement." Schuyler's own late work-joyous in spite of the poet's financial dissolution, mental instability, and physical decline-shows us that camp is one way of learning to love the waste we can't escape.

\section{Notes}

My thanks to Wayne Koestenbaum, Andy Fitch, Steven F. Kruger, Lisa Manter, and David Bergman for their contributions.

${ }^{1}$ Viewed through Andrew Ross's definition of camp, it becomes apparent that Ashbery's use of traditional poetic forms such as the sestina and pantoum are camp gestures in which new uses are found for outdated verse forms. In his late work, Ashbery often foregrounds the parodic aspects of this camp resuscitation, evident in his recent use of heroic couplets in A Worldly Country (2007): "A crescent moon / hung in the sky like a parrot on its perch. / Departing guests smiled and called, 'See you in church!'” (1). Ashbery's use of form pitches his poetry towards what critic Mark Silverberg calls Ashbery's "low-key camp," in which the humor depends on an unstable mixture of parody and profundity.

${ }^{2}$ For example, in the New York School section of Don Allen's groundbreaking anthology, The New American Poetry, 1945-1960, the first poems presented by both Kenneth Koch and Frank O'Hara feature waste prominently. Koch's "Mending Sump" concerns the plugging up of a sewage system; in O'Hara's "Chez Jane," a "tiger, / marvelously striped and irritable, leaps / on the table and without disturbing a hair / of the flowers' breathless attention, pisses / into the pot" (239).

3 "The Cenotaph," a poem directly preceding this suite in The Crystal Lithium, seems almost a response to Lowell's "Skunk Hour"; its first section depicts a trashloving canine who urinates on a smoldering incinerator.

${ }^{4}$ In Epistemology of the Closet, Eve Sedgwick, building on an insight by Robert Dawidoff, suggests that camp is a kind of reader relation. She writes that "the typifying gesture of camp is really something amazingly simple: the moment at which a consumer of culture makes the wild surmise, 'What if whoever made this was gay too? [...] What if the right audience for this were exactly $m e$ ? What if, for instance, the resistant, oblique, tangential investments of attention and attraction that I am able to bring to this spectacle are actually uncannily responsive to the resistant, oblique, tangential investments of the person, or of some of the people, who created it?" (156). Sedgwick posits camp as a kind of capitalist holding environment, in which gay subjects can recognize each other and create affiliations within an already-circulated object. I would add that this relationship may be especially powerful when embedded, as subtext, within a spectacle marketed primarily to a mainstream, heterosexual audience (e.g., the Miller girl, the Vargas girl).

${ }^{5}$ An example of both a camp object and a queer collaboration: in mid-career, Schuyler and Ashbery collaborated on a novel, A Nest of Ninnies. The novel is a sendup of suburban bourgeois mores, deriving much of its humor from its loving assassination of post-war America's commodification of tourism, especially food tourism and the domesticated exotica of the American dinner table.

${ }^{6}$ Both Julia Kristeva and Sherry B. Ortner have shown, from their different disciplinary vantage points, that waste and waste management are commonly and historically associated with the female sphere. Disgust at waste may thus underlie certain misogynistic and homophobic reactions. 
${ }^{7}$ In describing the poetic failures of four award-winning books by youngish poets, Vendler herself employs the culinary metaphor: "It is rarely something present and accounted for that is the cause of my dissatisfaction; it is something absent. A reader of a book, at this point, is rather like the chef in the kitchen tasting the dishes for the dinner-this doesn't have enough salt, this sauce is too thin, this has curdled, and who ever decided to put skinless chicken breast, cauliflower, and rice all on one white plate?" (Vendler "Four Prized Poets")

${ }^{8}$ In his wonderful poem, "Dining Out with Doug and Frank," Schuyler moves from describing his dinner to praising the restaurant's bathroom fixtures: "above the men's room door the / word Toilet is etched / on a transom. Beautiful lettering, / but nothing to what lurks / within: the three most / splendid urinals I've ever / seen. Like Roman Steles" (Collected Poems 247). Waste and taste-in both senses of the word-are imbricated in this gesture of camp connoisseurship.

In a more brazenly scatological mode, Schuyler's late poem, "White," addresses the bathroom of his Chelsea Hotel apartment, where he lived the last years of his life. Schuyler remedies a too-pristine repainting of his bathroom by taking "a dump / in my snowdrop-colored bathroom" (318).

${ }^{9}$ The Word-book of Virginia Folk-Speech defines "Dutchman's razor" as follows: "When a person treads in dung he is said to cut his foot with a Dutchman's razor" (161).

${ }^{10}$ For a thorough treatment of the subject, see Kathryn Bond Stockton's Beautiful Bottom, Beautiful Shame; the coda of Stockton's book, "Dark Camp: Behind and Ahead," is especially pertinent.

\section{Works Cited}

Allen, Don, ed. The New American Poetry, 1945-1960. $2^{\text {nd }}$ ed. Berkeley: UC Press, 1999.

Ashbery, John. A Worldly Country. New York: Ecco, 2007.

Ashbery, John and James Schuyler. A Nest of Ninnies. New York: Ecco, 1969.

Bataille, Georges. The Accursed Share: An Essay on General Economy. New York: Zone Books, 1988.

Bauman, Zygmunt. Wasted Lives: Modernity and its Outcasts. Oxford: Polity, 2004.

Bersani, Leo. "Is the Rectum a Grave?" October 43 (1987): 197-222.

Brown, Norman O. Life Against Death: The Psychoanalytic Meaning of History. $2^{\text {nd }}$ Ed. Middletown: Wesleyan, 1985.

Cleto, Fabio. Camp: Queer Aesthetics and the Performing Subject: A Reader. Ann Arbor: Michigan, 1999.

Di Piero, W. S. "Baby Sweetness Blew His Cool Again..." Poetry. Jan 2006: 307-17.

Eliot, T. S. The Waste Land: Authoritative Texts, Contexts, Criticism. Ed. Michael North. New York: Norton, 2001.

Flinn, Caryl. "The Deaths of Camp." Cleto, ed. 433-457.

Gooch, Brad. City Poet: The Life and Times of Frank O'Hara. New York: Knopf, 1993.

Green, Bennett Wood. Word-book of Virginia Folk-Speech. Richmond: Wm. Ellis Jones' Sons, Inc., 1899.

Herring, Terrell Scott. "Frank O'Hara's Open Closet." PMLA: Publication of 
the Modern Language Association of America 117.3 (2002): 414-27.

Lehman, David. The Last Avant-Garde: The Making of the New York School of Poets. New York: Doubleday, 1998.

Lowell, Robert. Collected Poems. Ed. Frank Bidart and David Gewanter. New York: Farrar, Straus and Giroux, 2003.

Koestenbaum, Wayne. Double Talk: The Erotics of Male Literary Collaboration. New York: Routledge, 1989.

Moon, Michael and Eve Kosofsky Sedgwick. "Divinity: A Dossier, A Performance Piece, A Little Understood Emotion." Tendencies. By Eve Kosofsky Sedgwick. Durham: Duke, 1993. 215-251.

O'Hara, Frank. The Collected Poems of Frank O'Hara. Ed. Donald Allen. Berkeley: UC Press, 1995.

Ronell, Avital. Crack Wars. Lincoln and London: University of Nebraska Press, 1992.

Ross, Andrew. "Uses of Camp." Cleto, ed. 308-329.

Schuyler, James. Collected Poems. New York: Farrar, Straus \& Giroux, 1993.

---. The Diary of James Schuyler. Santa Rosa, Ca.: Black Sparrow Press, 1997.

---. Just the Thing: Selected Letters of James Schuyler 1951-1991. New York: Turtle Point Press, 2004.

Sedgwick, Eve Kosofsky. Between Men: English Literature and Male Homosocial Desire. New York: Columbia, 1985.

---. Epistemology of the Closet. Berkeley: University of California, 1991.

Silverberg, Mark. "Laughter and Uncertainty: John Ashbery's Low-Key Camp." Contemporary Literature 43.2 (2002): 285-316.

Sontag, Susan. "Notes on Camp." Cleto, ed. 308-329.

Stockton, Kathryn Bond. Beautiful.Bottom, Beautiful Shame: Where "Black" Meets "Queer." Durham: Duke, 2006.

Vendler, Helen. "Four Prize Poets." The New York Review of Books. 17 August 1989. $6 \mathrm{Feb} 2008<\mathrm{http}: / /$ www.nybooks.com/articles/articlepreview?article_id=3943>.

---. "New York Pastoral." Soul Says. Cambridge: Harvard, 1995. 61-70. 